\title{
Chryseobacterium piscicola sp. nov., isolated from diseased salmonid fish
}

\author{
Pedro Ilardi, Jorge Fernández and Ruben Avendaño-Herrera \\ Laboratorio de Veterquímica, Camino Melipilla 5641, Cerrillos, Santiago, Chile
}

Correspondence

Ruben Avendaño-Herrera

reavendano@yahoo.com

\begin{abstract}
Eight bacterial strains isolated from diseased rainbow trout $(n=5)$ and Atlantic salmon $(n=3)$ were characterized by phenotypic and molecular taxonomic methods. The isolates were negative for the Gram-reaction, non-motile, rod-shaped and catalase- and oxidase-positive. Colonies on solid media were yellow, smooth, shiny and circular with regular edges. Growth occurred at $4-28{ }^{\circ} \mathrm{C}$ (optimum, $15{ }^{\circ} \mathrm{C}$ ) and with $0-3 \% \mathrm{NaCl}$ (optimum, $0.5 \%$ ). Analysis of the 16S rRNA gene sequence allocated the micro-organisms to the genus Chryseobacterium, with Chryseobacterium soldanellicola PSD1 $-4^{\top}$ and Chryseobacterium soli JS6- $6^{\top}$ as their closest relatives (96.9 and $97.1 \%$ sequence similarity, respectively). The levels of DNA-DNA hybridization towards these nearest phylogenetic neighbours were below $17.1 \%$. The DNA G+C contents of strains VQ-6316 $\mathrm{s}^{\top}$ and VQ-4836s were 32.5 and $32.3 \mathrm{~mol} \%$, respectively. The predominant menaquinone was MK- 6 and the major fatty acids were iso- $C_{15: 0}$, anteiso- $C_{15: 0}$, iso- $C_{17: 1} \omega 9 c$, iso- $\mathrm{C}_{17: 0} 3-\mathrm{OH}$ and summed feature 3 (comprising $\mathrm{C}_{16: 1} \omega 7 \mathrm{c}$ and/or $\mathrm{C}_{16: 1} \omega 7 \mathrm{t}$ and/or iso- $\mathrm{C}_{15: 0}$ $2-\mathrm{OH})$. The eight isolates were classified as representatives of a novel species, Chryseobacterium piscicola sp. nov., with strain VQ-6316s ${ }^{\top}\left(=\right.$ CECT $\left.7357^{\top}=\mathrm{DSM} 21068^{\top}\right)$ as the type strain.
\end{abstract}

The family Flavobacteriaceae represents the main bacterial lineage in the phylum 'Bacteroidetes' (formerly the Cytophaga-Flavobacterium-Bacteroides group) (Bernardet et al., 1996, 2002). Within this family, the genera Bergeyella, Chryseobacterium and Riemerella form a separate branch on the basis of rRNA cistron similarity studies and phenotypic characterization (Vandamme et al., 1994). At the time of writing, the genus Chryseobacterium comprised 38 species, some of which are pathogenic to humans and animals (Bernardet et al., 2002, 2005, 2006).

During the characterization of bacteria isolated from external lesions of diseased farmed Atlantic salmon (Salmo salar) and rainbow trout (Oncorhynchus mykiss) in Osorno, Chile, eight yellow-pigmented strains were recovered on modified Anacker and Ordal's agar (AOA; $0.5 \%$ tryptone, $0.05 \%$ yeast extract, $0.02 \%$ beef extract, $0.02 \%$ sodium acetate, $\mathrm{pH} 7.2$; Anacker \& Ordal, 1955) incubated at $15{ }^{\circ} \mathrm{C}$. Five strains were isolated from rainbow trout (VQ-106r, VQ-5916r, VQ-5946r, VQ-5926r, VQ5966r) and the remaining three isolates (VQ-2206s, VQ4836s, VQ-6316s ${ }^{\mathrm{T}}$ ) were recovered from Atlantic salmon. Strains were routinely cultured aerobically on AOA at $15{ }^{\circ} \mathrm{C}$ for 3 days. Stock cultures were preserved at $-80{ }^{\circ} \mathrm{C}$

The GenBank/EMBL/DDBJ accession numbers for the 16S rRNA gene sequences of strains VQ-106r, VQ-4836s and VQ-6316s ${ }^{\top}$ are EU869188-EU869190, respectively.

An electron micrograph of cells of strain $V Q-6316 s^{\top}$ and a table giving API ZYM profiles are available with the online version of this paper. in Criobilles tubes (AES Laboratory). The diseased fish showed the typical signs (i.e. skin and muscle ulcerative lesions on the flank and in the anus or peduncle area) observed in fish affected by Flavobacterium psychrophilum, the causative agent of bacterial cold-water disease and rainbow trout fry syndrome (Ilardi \& Avendaño-Herrera, 2008). However, a comparative analysis of $16 \mathrm{~S}$ rRNA gene sequences indicated that all the isolates were members of the genus Chryseobacterium. Although they were only retrieved from superficial lesions, not from internal organs, their virulence for fish has been demonstrated (Ilardi \& Avendaño-Herrera, 2008). In order to determine the exact taxonomic position of the new isolates, a taxonomic study was performed using a polyphasic approach.

PCR amplification of the 16S rRNA genes of the eight isolates was conducted using universal primers $20 \mathrm{~F}$ and 1500R (Weisburg et al., 1991) and PCR products were purified using QIAquick PCR purification kits (Qiagen). The 16S rRNA gene sequence was determined directly using the PCR-amplified DNA as a sequencing template on an ABI PRISM 310 sequencer (Applied Biosystems) according to the manufacturer's recommendations. The resulting sequences were compared with those available in GenBank, EMBL (http://www.ebi.ac.uk) and the Ribosomal Database Project using the program BLAST. Multiple alignments were performed using the CLUSTAL_X program (Thompson et al., 1997) and a phylogenetic tree was constructed using the neighbour-joining method with MEGA3 software (Kumar et al., 2004). All isolates formed a 
robust cluster within the genus Chryseobacterium. Data from sequence similarity analysis indicated that the closest relatives of the eight strains were Chryseobacterium soldanellicola PSD1-4 ${ }^{\mathrm{T}}$ and Chryseobacterium soli JS6-6 ${ }^{\mathrm{T}}$, exhibiting 96.9 and $97.1 \%$ 16S rRNA gene sequence similarities, respectively (Fig. 1). Interestingly, when the sequence of strain VQ-6316s ${ }^{T}$ was compared with those of Chryseobacterium strains isolated from fish published by Bernardet et al. (2005), it shared nearly $100 \%$ sequence similarity with strains UOF CR4395 and UOF CR2995 (GenBank accession nos AY468455 and AY468454, respectively), isolated from Atlantic salmon in Finland.
DNA-DNA hybridization was performed as described by De Ley et al. (1970) with the modifications of Huß et al. (1983) using a model Cary 100 Bio UV/VISspectrophotometer equipped with a Peltier-thermostatted $6 \times 6$ multicell changer and a temperature controller with in situ temperature probe (Varian). The levels of DNA-DNA relatedness between strain VQ-6316s $\mathrm{s}^{\mathrm{T}}$ and strain VQ-5926r, C. soldanellicola PSD1-4 ${ }^{\mathrm{T}}$ and C. soli JS6-6 ${ }^{\mathrm{T}}$ were 99.2, 17.1 and $13.2 \%$, respectively, demonstrating that the isolates formed a tight group that was distinct from recognized species of the genus Chryseobacterium.

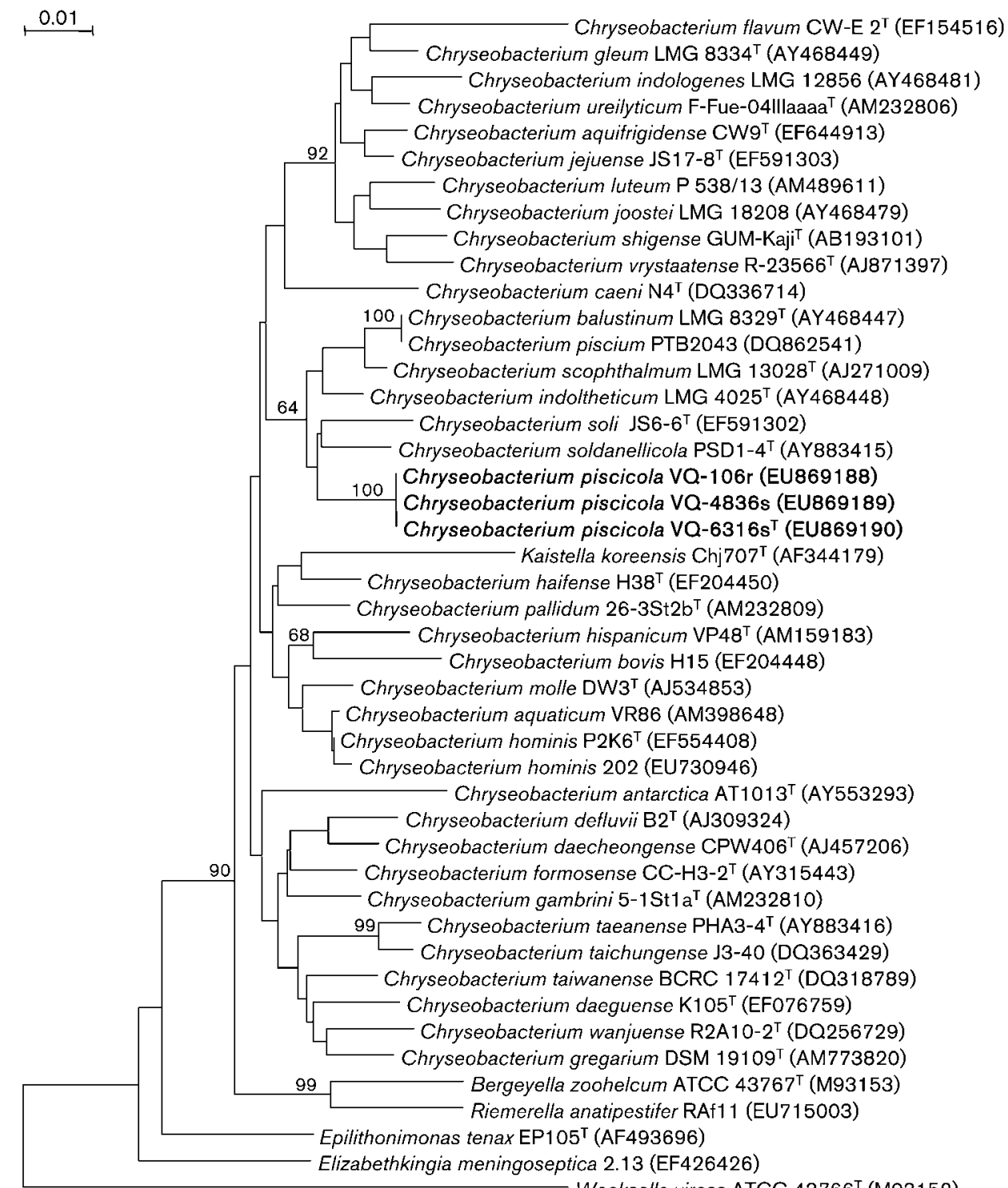

Weeksella virosa ATCC $43766^{\top}$ (M93152)

Fig. 1. Neighbour-joining phylogenetic tree, based on 16S rRNA gene sequences, showing the relationships between the fish isolates, other members of the genus Chryseobacterium and representatives of other related genera in the family Flavobacteriaceae. Weeksella virosa ATCC $43766^{\top}$ was used as an outgroup. Bootstrap values $>50 \%$ are shown at nodes. Bar, 0.01 substitutions per nucleotide position. 
Phenotypic characterization of the eight isolates was carried out as described by Bernardet et al. (2002) and according to standard methods (MacFaddin, 1980). The Gram reaction was tested by using the bioMérieux Gramstain kit according to the manufacturer's instructions and the non-staining $\mathrm{KOH}$ method (Buck, 1982). Gliding motility was assessed by phase-contrast microscopy on a fresh Anacker and Ordal's broth culture by the hanging drop technique (Bernardet et al., 2002). The presence of flexirubin-type pigments and cell wall-associated galactosamine glycans was assessed by adding $20 \% \mathrm{KOH}$ or $0.01 \%$ Congo red (Sigma), respectively, to 3-day-old colonies (Bernardet et al., 2002; Avendaño-Herrera et al., 2004). Cytochrome oxidase activity (using $N, N, N^{\prime}, N^{\prime}$-tetramethyl-p-phenylenediamine; Sigma) and catalase production (using $3 \% \mathrm{H}_{2} \mathrm{O}_{2}$ ) were determined on glass slides. The following tests were performed according to MacFaddin (1980): oxidation/fermentation reactions, VogesProskauer reaction and arginine dihydrolase, lysine decarboxylase and ornithine decarboxylase activities.

Hydrolysis of the following substrates was determined using $\mathrm{AOA}$ as the basal medium: gelatin (1\%), agar (3\%), starch (1\%), Tween $80(1 \%)$, casein (1\%), DNA (1\%), sheep blood (5\%) and tyrosine $(0.1 \%)$. Growth was tested at $0,4,15,28,37$ and $42{ }^{\circ} \mathrm{C}$ on AOA. Growth in the presence of $0,1,1.5,3$ and $6 \%(\mathrm{w} / \mathrm{v}) \mathrm{NaCl}$ was also determined. Growth was tested on MacConkey, Simmons' citrate, blood, R2A, marine 2216, nutrient and tryptone soy agars. Enzymic activities were assessed using API ZYM (bioMérieux) strips according to the manufacturer's instructions, with the exception that the incubation temperature was $15{ }^{\circ} \mathrm{C}$.

The morphology of bacterial cells grown for $48 \mathrm{~h}$ on AOA was observed by light $(1000 \times$ magnification $)$ and transmission electron (100SX; JEOL) microscopy. Cells were prepared for electron microscopy as described by Spurr (1969) and Reynolds (1963).

The results of the phenotypic analyses of the eight isolates are given in the species description and in Table 1 and those from API ZYM tests are given in Supplementary Table S1 (available in IJSEM Online).

The respiratory quinones of strains VQ- $6316 \mathrm{~s}^{\mathrm{T}}$ and VQ4836s were analysed using reverse-phase HPLC by the Identification Service of the Deutsche Sammlung von Mikroorganismen und Zellkulturen GmbH (DSMZ, Braunschweig, Germany). The major peak identified was that of menaquinone MK-6, which is consistent with that present in all other members of the family Flavobacteriaceae.

The fatty acids of strains VQ- $6316 s^{\mathrm{T}}$ and VQ-4836s were extracted from cells grown on AOA at $15{ }^{\circ} \mathrm{C}$ for $48 \mathrm{~h}$, methylated and analysed using the standard protocol of the Microbial Identification System (MIDI, Microbial ID) at

Table 1. Phenotypic characteristics that differentiate Chryseobacterium piscicola sp. nov. from closely related Chryseobacterium species

Taxa (the number of strains examined, when greater than 1, is given in parentheses): 1 , C. piscicola sp. nov. ( $n=8) ; 2$, C. soldanellicola PSD1-4 ${ }^{\mathrm{T}}$ (Park et al., 2006); 3, C. scophthalmum ( $n=2)$; 4, C. piscium ( $n=4$; de Beer et al., 2006); 5, C. balustinum LMG 8329 ; 6, C. soli ( $n=2)$ (Weon et al., 2008); 7, C. indoltheticum LMG 4025 ${ }^{\mathrm{T}}$. Except where indicated otherwise, data for taxa 3, 5 and 6 are from Hugo et al. (2003). +, Positive; W, weakly positive; -, negative; $\mathrm{v}$, variable; $\mathrm{D}$, delayed; NA, no data available.

\begin{tabular}{|c|c|c|c|c|c|c|c|}
\hline Characteristic & 1 & 2 & 3 & 4 & 5 & 6 & 7 \\
\hline MacConkey agar & - & - & - & - & + & + & + \\
\hline $37^{\circ} \mathrm{C}$ & - & + & - & - & + & $\mathrm{V}$ & - \\
\hline \multicolumn{8}{|l|}{ Enzyme activities } \\
\hline DNase & $\mathrm{W}$ & - & + & $\mathrm{D}$ & + & - & + \\
\hline \multicolumn{8}{|l|}{ Hydrolysis of: } \\
\hline Starch & - & NA & - & - & - & + & - \\
\hline Tween 80 & - & - & + & $\mathrm{V}$ & + & + & + \\
\hline Tyrosine & - & NA & + & - & - & + & + \\
\hline \multicolumn{8}{|l|}{ Production of: } \\
\hline
\end{tabular}

${ }^{\star}$ Refers to type strain.

$\dagger$ Mean DNA G + C content calculated for six reference strains plus the type strain (data from Mudarris et al., 1994). 
the DSMZ as described by Sasser (1990). The predominant fatty acids (mean values) were: iso- $\mathrm{C}_{15: 0}, 36.2 \%$; anteiso$\mathrm{C}_{15: 0}, 13.9 \%$; iso- $\mathrm{C}_{17: 1} \omega 9 \mathrm{c}, 11.1 \%$; iso- $\mathrm{C}_{17: 0} 3-\mathrm{OH}$, $10.5 \%$; and summed feature 3 (comprising $\mathrm{C}_{16: 1} \omega 7 c$ and/or $\mathrm{C}_{16: 1} \omega 7 t$ and/or iso- $\left.\mathrm{C}_{15: 0} \quad 2-\mathrm{OH}\right), \quad 11.2 \%$. Detailed fatty acid profiles of the novel isolates and their closest relatives are presented in Table 2.

Genomic DNA was purified following the method of Cashion et al. (1977) and the DNA G + C content was determined using the HPLC method according to Mesbah et al. (1989) by the DSMZ. The DNA G +C contents of strains VQ-6316s ${ }^{\mathrm{T}}$ and VQ-4836s were 32.5 and $32.3 \mathrm{~mol} \%$, respectively. These values fall within the range (29-39 mol\%) reported for members of the genus Chryseobacterium by Bernardet et al. (2006).

On the basis of the results obtained, the new isolates are sufficiently distinct from all recognized species of the genus Chryseobacterium to be assigned as representatives of a novel species of this genus, for which the name Chryseobacterium piscicola sp. nov. is proposed.

\section{Description of Chryseobacterium piscicola sp. nov.}

Chryseobacterium piscicola [pis.ci'cola. L. n. piscis fish; L. suff. - cola (from L. n. incola) inhabitant; N.L. n. piscicola an inhabitant of fish].
Cells are Gram-reaction-negative, non-motile rods approximately $1.6-3.5 \mu \mathrm{m}$ in length and $0.8-1.2 \mu \mathrm{m}$ in diameter (see Supplementary Fig. S1 available in IJSEM Online). Catalase- and oxidase-positive and non-fermentative. Colonies are smooth, shiny, circular with regular edges and yellow in colour. Flexirubin pigments are produced, but Congo red is not absorbed. Grows at 4$28{ }^{\circ} \mathrm{C}$ (optimum, $15{ }^{\circ} \mathrm{C}$ ) and with $0-3 \% \mathrm{NaCl}$ (optimum, $0.5 \%)$. Good growth occurs on blood ( $\alpha$-haemolytic), R2A, nutrient and tryptone soy agars, but no growth occurs on MacConkey, marine 2216 or Simmons' citrate agars. Gelatin and aesculin are hydrolysed, but Tween 80, tyrosine, agar, starch and casein are not. All strains are negative for arginine dihydrolase, lysine decarboxylase and ornithine decarboxylase activities. DNA reaction is weakly positive. Nitrate and nitrite are not reduced. The methyl red and Voges-Proskauer tests are negative. In the API ZYM system, alkaline phosphatase, esterase, esterase lipase, lipase, leucine arylamidase, valine arylamidase, cystine arylamidase, $\alpha$-chymotrypsin, acid phosphatase, naphthol-AS-BI-phosphohydrolase, $\beta$-glucuronidase, $\alpha$ glucosidase, $\beta$-glucosidase and $N$-acetyl- $\beta$-glucosaminidase activities are present, but trypsin, $\alpha$-galactosidase, $\beta$ galactosidase, $\alpha$-mannosidase and $\alpha$-fucosidase activities are absent. The predominant menaquinone is MK-6 and the major $(>10 \%)$ fatty acids are iso- $\mathrm{C}_{15: 0}$, anteiso- $\mathrm{C}_{15: 0}$, iso- $\mathrm{C}_{17: 1} \omega 9 c$, iso- $\mathrm{C}_{17: 0} 3-\mathrm{OH}$ and summed feature 3

Table 2. Cellular fatty acid content (\%) of Chryseobacterium piscicola sp. nov. and closely related species of the genus Chryseobacterium

Taxa: 1, C. piscicola sp. nov. ( $n=2) ; 2$, C. soldanellicola PSD1-4 ${ }^{\mathrm{T}}$ (Park et al., 2006); 3, C. scophthalmum ( $\left.n=2\right)$; 4, . piscium ( $n=4$; de Beer et al., 2006); 5, C. balustinum LMG $8329^{\mathrm{T}}$; 6, C. soli JS6-6 ${ }^{\mathrm{T}}$ (Weon et al., 2008); 7, C. indoltheticum LMG $4025^{\mathrm{T}}$. Data for taxa 3,5 and 6 are taken from Hugo et al. (2003). Values derived from more than one strain are mean \pm SD. ND, Not detected; NR, not reported; tr, trace (less than $1.0 \%)$. Fatty acids amounting to $<1 \%$ of the total fatty acids in all strains studied are omitted. Different culture conditions were used.

\begin{tabular}{|c|c|c|c|c|c|c|c|}
\hline Fatty acid & 1 & 2 & 3 & 4 & 5 & 6 & 7 \\
\hline iso- $\mathrm{C}_{13: 0}$ & $2.4 \pm 0.8$ & $\operatorname{tr}$ & $\operatorname{tr}$ & $\operatorname{tr}$ & $\operatorname{tr}$ & 1.0 & ND \\
\hline Unknown $13.566^{*}$ & $1.3 \pm 0.5$ & 2.3 & $2.9 \pm 0.2$ & $\operatorname{tr}$ & 1.6 & $\mathrm{NR}$ & 1.7 \\
\hline iso- $\mathrm{C}_{15: 0}$ & $36.2 \pm 0.2$ & 41.8 & $35.0 \pm 0.7$ & $38.3 \pm 5.0$ & 32.3 & 15.7 & 29.4 \\
\hline anteiso- $\mathrm{C}_{15: 0}$ & $13.9 \pm 0.0$ & 1.9 & $\operatorname{tr}$ & $2.7 \pm 1.9$ & $\operatorname{tr}$ & 3.8 & 5.9 \\
\hline iso- $\mathrm{C}_{16: 0}$ & $1.0 \pm 0.1$ & NR & NR & NR & NR & 1.6 & NR \\
\hline $\mathrm{C}_{16: 0}$ & $2.0 \pm 0.2$ & 1.4 & $1.2 \pm 0.2$ & $1.1 \pm 0.2$ & 1.6 & 5.8 & 1.0 \\
\hline iso- $\mathrm{C}_{15: 0} 3-\mathrm{OH}$ & $2.1 \pm 0.0$ & 2.7 & $2.7 \pm 0.1$ & $2.4 \pm 0.3$ & 2.7 & 2.4 & 2.3 \\
\hline iso- $\mathrm{C}_{17: 1} \omega 9 c$ & $11.1 \pm 0.2$ & 14.6 & $24.8 \pm 0.4$ & $18.7 \pm 2.8$ & 27.1 & 15.5 & 25.6 \\
\hline Unknown $16.580^{*}$ & tr & 1.5 & $1.5 \pm 0.5$ & $1.2 \pm 0.2$ & 1.3 & $\mathrm{NR}$ & 1.3 \\
\hline iso- $\mathrm{C}_{17: 0}$ & $\operatorname{tr}$ & $\operatorname{tr}$ & $\operatorname{tr}$ & $1.2 \pm 0.2$ & 1.0 & NR & $\operatorname{tr}$ \\
\hline iso- $\mathrm{C}_{16: 0} 3-\mathrm{OH}$ & $\operatorname{tr}$ & $\operatorname{tr}$ & $\operatorname{tr}$ & $\operatorname{tr}$ & $\operatorname{tr}$ & 2.1 & 1.3 \\
\hline $\mathrm{C}_{16: 0} 3-\mathrm{OH}$ & $2.2 \pm 0.1$ & 1.3 & $1.0 \pm 0.1$ & $1.3 \pm 0.3$ & 1.4 & 2.2 & $\operatorname{tr}$ \\
\hline $\mathrm{C}_{18: 1} \omega 5 c$ & $\operatorname{tr}$ & $\operatorname{tr}$ & NR & $\mathrm{NR}$ & $\operatorname{tr}$ & 1.1 & $\operatorname{tr}$ \\
\hline iso- $\mathrm{C}_{17: 0} 3-\mathrm{OH}$ & $10.5 \pm 0.1$ & 17.7 & $16.3 \pm 0.1$ & $16.2 \pm 3.1$ & 16.8 & 15.0 & 14.0 \\
\hline $\mathrm{C}_{17: 0} 2-\mathrm{OH}$ & $1.5 \pm 0.0$ & $\operatorname{tr}$ & NR & NR & $\operatorname{tr}$ & 2.3 & 3.0 \\
\hline Summed feature $3 \dagger$ & $11.2 \pm 0.5$ & ND & NR & $10.8 \pm 1.3$ & $\operatorname{tr}$ & 12.0 & NR \\
\hline
\end{tabular}

*Unknown fatty acid; numbers indicate the equivalent chain-length.

$†$ Summed features are groups of two or three fatty acids that cannot be separated by GLC using MIDI systems. Summed feature 3 comprised $\mathrm{C}_{16: 1} \omega 7 c$ and/or $\mathrm{C}_{16: 1} \omega 7 t$ and/or iso- $\mathrm{C}_{15: 0} 2-\mathrm{OH}$. 
(comprising $\mathrm{C}_{16: 1} \omega 7 c$ and/or $\mathrm{C}_{16: 1} \omega 7 t$ and/or iso- $\mathrm{C}_{15: 0}$ 2-OH).

The type strain, VQ- $6316 \mathrm{~s}^{\mathrm{T}} \quad\left(=\mathrm{CECT} \quad 7357^{\mathrm{T}}=\mathrm{DSM}\right.$ $\left.21068^{\mathrm{T}}\right)$, was isolated from diseased Atlantic salmon (Salmo salar) farmed in Osorno, Chile. The DNA G + C content of the type strain is $32.5 \mathrm{~mol} \%$.

\section{Acknowledgements}

This work was supported by grant IPC 019 from the Program Bicentenario Ciencia y Tecnología, CONICYT, Chile. R.A.-H was also supported in part by this Grant. Thanks are expressed to members of the technical team of the laboratories of Veterquímica. The authors wish to express their gratitude to Dr J.-F. Bernardet, Institut National de la Recherche Agronomique, Unité de Virologie et Immunologie Moléculaires, for reviewing and editing the manuscript.

\section{References}

Anacker, R. L. \& Ordal, E. J. (1955). Study of a bacteriophage infecting the myxobacterium Chondrococcus columnaris. J Bacteriol 70, 738-741.

Avendaño-Herrera, R., Magariños, B., López-Romalde, S., Romalde, J. L. \& Toranzo, A. E. (2004). Phenotypic characterization and description of two major O-serotypes in Tenacibaculum maritimum strains isolated from marine fishes. Dis Aquat Organ 58, 1-8.

Bernardet, J.-F., Segers, P., Vancanneyt, M., Berthe, F., Kersters, K. \& Vandamme, P. (1996). Cutting a Gordian knot: emended classification and description of the genus Flavobacterium, emended description of the family Flavobacteriaceae, and proposal of Flavobacterium hydatis nom. nov. (basonym, Cytophaga aquatilis Strohl and Tait 1978). Int J Syst Bacteriol 46, 128-148.

Bernardet, J.-F., Nakagawa, Y. \& Holmes, B. (2002). Proposed minimal standards for describing new taxa of the family Flavobacteriaceae and emended description of the family. Int J Syst Evol Microbiol 52, 1049-1070.

Bernardet, J.-F., Vancanneyt, M., Matte-Tailliez, O., Grisez, L., Tailliez, P., Bizet, C., Nowakowski, M., Kerouault, B. \& Swings, J. (2005). Polyphasic study of Chryseobacterium strain isolated from diseased aquatic animals. Syst Appl Microbiol 28, 640-660.

Bernardet, J.-F., Hugo, C. \& Bruun, B. (2006). The genera Chryseobacterium and Elizabethkingia. In The Prokaryotes. A Handbook on the Biology of Bacteria, 3rd edn, vol. 7, pp. 638-676. Edited by M. Dworkin, S. Falkow, E. Rosenberg, K. H. Schleifer \& E. Stackebrandt. New York: Springer-Verlag.

Buck, J. D. (1982). Nonstaining (KOH) method for determination of gram reactions of marine bacteria. Appl Environ Microbiol 44, 992-993.

Cashion, P., Holder-Franklin, M. A., McCully, J. \& Franklin, M. (1977). A rapid method for base ratio determination of bacterial DNA. Anal Biochem 81, 461-466.

de Beer, H., Hugo, C. J., Jooste, P. J., Vancanneyt, M., Coenye, T. \& Vandamme, P. (2006). Chryseobacterium piscium sp. nov., isolated from fish of the South Atlantic Ocean off South Africa. Int J Syst Evol Microbiol 56, 1317-1322.

De Ley, J., Cattoir, H. \& Reynaerts, A. (1970). The quantitative measurement of DNA hybridization from renaturation rates. Eur $J$ Biochem 12, 133-142.

Hugo, C. J., Segers, P., Hoste, B., Vancanneyt, M. \& Kersters, K. (2003). Chryseobacterium joostei sp. nov., isolated from the dairy environment. Int J Syst Evol Microbiol 53, 771-777.

Huß, V. A. R., Festl, H. \& Schleifer, K. H. (1983). Studies on the spectrophotometric determination of DNA hybridization from renaturation rates. Syst Appl Microbiol 4, 184-192.

Ilardi, P. \& Avendaño-Herrera, R. (2008). Isolation of Flavobacteriumlike bacteria from diseased salmonids cultured in Chile. Bull Eur Assoc Fish Pathol 28, 176-185.

Kumar, S., Tamura, K. \& Nei, M. (2004). MEGA3: integrated software for molecular evolutionary genetic analysis and sequence alignment. Brief Bioinform 5, 150-163.

MacFaddin, J. F. (1980). Biochemical Tests for Identification of Medical Bacteria, 2nd edn. Baltimore, MD: Williams \& Wilkins.

Mesbah, M., Premachandran, U. \& Whitman, W. B. (1989). Precise measurement of the $\mathrm{G}+\mathrm{C}$ content of deoxyribonucleic acid by highperformance liquid chromatography. Int J Syst Bacteriol 39, 159-167.

Mudarris, M., Austin, B., Segers, P., Vancanneyt, M., Hoste, B. \& Bernardet, J.-F. (1994). Flavobacterium scophthalmum sp. nov., a pathogen of turbot (Scophthalmus maximus L.). Int J Syst Bacteriol 44, 447-453.

Park, M. S., Jung, S. R., Lee, K. H., Lee, M.-S., Do, J. O., Kim, S. B. \& Bae, K. B. (2006). Chryseobacterium soldanellicola sp. nov. and Chryseobacterium taeanense sp. nov., isolated from roots of sand-dune plants. Int J Syst Evol Microbiol 56, 433-438.

Reynolds, E. S. (1963). The use of lead citrate at high $\mathrm{pH}$ as an electron-opaque stain in electron microscopy. J Cell Biol 17, 208-212.

Sasser, M. (1990). Identification of bacteria by gas chromatography of cellular fatty acids, MIDI Technical Note 101. Newark, DE: MIDI Inc.

Spurr, A. R. (1969). A low-viscosity epoxy resin embedding medium for electron microscopy. J Ultrastruct Res 26, 31-43.

Thompson, J. D., Gibson, T. J., Plewniak, F., Jeanmougin, F. \& Higgins, D. G. (1997). The CLUSTAL_X windows interface: flexible strategies for multiple sequence alignment aided by quality analysis tools. Nucleic Acids Res 25, 4876-4882.

Vandamme, P., Bernardet, J.-F., Segers, P., Kersters, K. \& Holmes, B. (1994). New perspectives in the classification of the flavobacteria: description of Chryseobacterium gen. nov., Bergeyella gen. nov., and Empedobacter nom. rev. Int J Syst Bacteriol 44, 827-831.

Weisburg, W. G., Barns, S. M., Pelletier, D. A. \& Lane, D. J. (1991). $16 \mathrm{~S}$ ribosomal DNA amplification for phylogenetic study. J Bacteriol 173, 697-703.

Weon, H.-Y., Kim, B.-Y., Yoo, S.-H., Kwon, S.-W., Stackebrandt, E. \& Go, S.-J. (2008). Chryseobacterium soli sp. nov. and Chryseobacterium jejuense sp. nov., isolated from soil samples from Jeju, Korea. Int J Syst Evol Microbiol 58, 470-473. 